\title{
Synergies and Balance between Values Education and Quality Teaching
}

\author{
Terence Lovat \\ Professor of Education \\ The University of Newcastle \\ NSW 2308 \\ AUSTRALIA \\ Terry.Lovat@newcastle.edu.au
}

\begin{abstract}
The article will focus on the implicit values dimension that is evident research findings around quality teaching. Furthermore, it sets out to demonstrate that maximizing the effects of quality teaching requires explicit attention to this values dimension and that this can be achieved through a well-crafted values education program. Evidence for this latter claim will come from international studies as well as from the Australian Government's Values Education Program and, especially from the Values Education Good Practice Schools Project Stage 1 Report (DEST 2006).
\end{abstract}




\section{Introduction: The Power of Quality Teaching}

It was the Carnegie Corporation's 1994 Task Force on Learning (Carnegie, 1994) that in many ways impelled the modern era of quality teaching. It represented a turningpoint in the dominant conceptions placed on the role of the school and, in turn, on the power of teaching to effect change in student achievement. It utilized an amassing body of research knowledge that showed flaws in earlier conceptions around the limited power of schooling to impact positively on student development. In particular, it took on the dominant conceptions of the likes of Parsons (Parsons \& Bales, 1955), Coleman (Coleman et al., 1966) and Jencks (Jencks, 1972) that had identified student achievement as being determined almost solely by student background with schools having little impact on student outcomes. Likewise, the Plowden Report (Central Advisory Council for Education, UK,1967) had concluded that any influence of schools on students' academic success was minimal (Reynolds, Hargreaves, \& Blackstone, 1980). These reports presented a pessimistic view of the power of teachers and education generally to influence student achievement, on the basis that social and economic disadvantage were its most powerful determinants.

While student achievement in this context was largely defined in academic terms, similar conclusions had been reached regarding all manner of personal and social education. Indeed, if research seemed to reveal the fragile nature of optimism that teachers and schools could influence change in academic prowess, the only conclusion to be drawn about attempts to influence personal, moral or character development was that it was on even more fragile grounds (see Leming, 1993; Lickona, 1993). This resulted in a de facto values-neutral stance being taken by schools. This stance was based on the belief that educational interventions were both ethically inappropriate and educationally doomed.

In recent times, these forms of pessimism regarding the power of educational interventions both on students' academic achievement and their moral formation have been challenged by the seemingly powerful effects of quality teaching and by an attached recognition about the implausibility and inadequacy of a values-neutral approach being taken to such an inherently values-filled endeavour as education. In this regard, the Carnegie Task Force was also crucial in its definition of the range of learning skills that should be seen as constituting student achievement. By this, it began to blur the boundaries between what would normally be regarded as academic achievement and other core learning pertinent to education. Beyond the more predictable aspects of intellectual development, the Task Force report introduced for the modern era notions of learning concerned with communication, empathy, reflection and self-management. It was also explicit in making the point that, while heritage and upbringing could make a difference to the ease with which these forms of learning could be attained, they were in no way certain predictors of success.

Consistent with the era of quality teaching which the report in some ways ushered in, the final onus was placed on the school (especially the early years of school) and the teacher to make the difference.

Pointing to the inadequacy of surface learning, the Carnegie Report emphasized that effective learning unleashes within the learner the cognitive, affective and conative energies that engage, empower and effect learning of genuine depth. The nature of such a learning experience was elaborated by Newmann and Associates (1996; 
Newmann, Marks, \& Gamoran, 1996) whose work focussed on the pedagogical dynamics needed to engage students at sufficient 'intellectual depth' in order to motivate and empower their learning. This would mean restructuring the whole learning environment for the benefit of student achievement and would involve: pedagogical strategies and techniques used by teachers; catering for the diverse needs of students; organizing of schools for the express purpose of student achievement (school coherence); professional development of teachers; and, the creation of a trustful, supportive ambience in the school. In a word, development of the whole person was seen to require both implicit modelling and explicit teaching.

In the search for successful restructuring of schools for the benefit of student achievement, Linda Darling-Hammond (1996; 1998; 2000; Darling-Hammond \& Youngs, 2002), herself a member of the Carnegie Task Force, engaged in intensive work that underlined the crucial role of the teacher. Her work rendered evidence that student achievement is predicted less by a range of independent variables, such as student demographics, teacher salaries, levels of expenditure and class sizes, than by a teacher's subject and pedagogical knowledge. High quality subject and pedagogical knowledge (or 'quality teaching') proved to have the single greatest impact on student success, when measured against the wide array of other factors of influence. Alternatively, poor or ineffective teaching was found to have a cumulative and enduring debilitative effect (cf. Fallon, 2003).

Extensive evidence-based research, literature searches and meta-analyses over the last decade have repeatedly demonstrated that the quality of the teaching and learning environment has huge potential to overturn the effects of disadvantage related to an array of variables, including family background, socio-economic status and even disability of sorts (e.g. Alton-Lee, 2003; Avery, 1999; Hattie, 2004; King, Schroeder, \& Chawszczewski, 2001; Scheerens, Vermeulen, \& Pelgrum, 1989; Rowe, 2004). Furthermore, allied research like that of Noddings (1997), Carr (2002) and Willms' (2000) has shown what power a quality teaching and learning environment can have in matters of self-esteem, security and wellbeing. Hence, evidence is building that indicates that the potency of quality teaching is not restricted to pedagogical techniques solely concerned with subject content and academic processes, but that its efficacy also lies in attending to the affective dimension of teaching and learning, and to all the attachments to this concerned with the coherence, ambience and relationships that characterize the learning environment.

In other words, quality teaching has demonstrated the true and full power of the teacher to make a difference in student learning not only around factual knowledge, but around social and personal knowing as well (after Habermas, 1972; see also Lovat \& Smith, 2003). The essence of quality teaching lies in the synergy and balance between these different ways of knowing. Quality teaching has alerted the educational community to the greater potential of teaching, including in such areas as personal and social values inculcation. As such, it has huge relevance to values education. Moreover, the reverse case could be argued, namely, that when properly and comprehensively understood, values education has the potential to complement and complete the goals implicit in quality teaching regimes. Furthermore, it might even have the potential to temper some of these goals, especially when systems set out to reduce them to those they can most easily control, rate and measure. 


\section{Quality Teaching and the Tempering Power of Values}

If there is a danger lurking behind the new and invigorating findings emanating in the name of quality teaching, it is that there is the potential over time for it to become as much a victim of instrumentalist thought and technicist practice as many of the regimes it has superseded. The notions that characterize quality teaching are not beyond being reduced to those fixed, politicized and supposedly-easily-measured formulas that eventually characterized regimes built around notions like objectives, outcomes, competencies and, indeed, intellectual quotient (IQ) in earlier times. If it is to endure, the challenge for regimes built around quality teaching will be to avoid, or at least temper, the inclination towards reducing good ideas to formulas that tends to happen when systems set out to control and standardize the products of research. A focus on values and the complementarity of values education is one way in which this might be achieved, for this focus serves as a constant reminder that there is in fact no magic in a formula and that student achievement is a complex notion that defies ease of instrumentalist forms of measurement, being determined rather by a wide range of factors, some easily measured, some measured with greater difficulty, but some which could never be measured by even the cleverest of instruments.

The values dimension therefore can serve as a corrective to those technicist approaches to teaching that serve to reduce teaching performance to mechanistic and instrumentalist criteria, underpinned by the quaint notion that such criteria are objective and therefore values-free. This conception of teaching ignores the insights of research (cf. Halliday, 1998; Hansen, 1998; Haberman, 2002; Campbell, Kyriakides, Muijs, Robinson, 2004; Carr, 2005, 2006) that have demonstrated the poverty and futility of a technicist-only frame of reference to learning. These research insights speak variously of effective teaching being characterized by its explicitness as a moral activity (Halliday), of it entailing forms of insight into human interaction, of it entailing deep forms of understanding, judgement, appreciation and sensibility (Carr 2005), that it is inherently interpersonal (Hansen), and requiring quality of character that needs conscious and intentional self-development (Haberman). Furthermore, its effectiveness is said to rest on the communicative ability of teachers to empathize and communicate intuitively with students in such a way as to bridge the cultural and social divides that would otherwise be barriers to student learning (Carr 2006).

In similar vein, Rowe's (2004) ACER study around students ‘doing well’ noted that, when factor analysed, issues of teacher care and student trust were identified by students even more often than teacher knowledge and pedagogical craft as those features about teacher practice that impacted most positively on their 'doing well'. In a related study, Louden et al. (2004) concluded that educability was as much influenced by the personal relationship between elder and younger person as by the more explicit teaching relationship between practitioner and student. In some extreme instances, the study seemed to find that superior student effect could actually emanate from situations where teacher practice was questionable in terms of the most updated content and pedagogy but, against this, where a positive relationship existed between teacher and student.

The profound influence of the student-teacher relationship to effect student attainment is observed by others. Hattie (2004) identified one of the five dimensions characteristic of expert teachers attending to the affective attributes of teaching as 
'high respect for students'. In determining the features of positive learning, Brady (2005) elevates the importance of personal relationships, approachability, and the provision of a warm and empathic environment to at least the same level as the proficient implementation of pedagogical strategies. According to Deakin-Crick and Wilson (2005), the quality of classroom relationships is critical in supporting the nurturing of those values, attitudes and dispositions needed to accept personal responsibility for life-long learning. This concurs with Wentzel's (1997) findings that, when students feel valued and supported, they are likely to be more motivated to learn. Similarly, Khine and Fisher (2004) observed the powerfully determining effect of positive interaction by teachers on student learning. These studies all reflect Noddings' (1997) earlier and foundational observation that it is the caring relationship that will invariably precede student engagement with learning.

This profound connection between values and a student's capacity and motivation to learn is articulated by Cawsey (2002) in the following way:

There is considerable anecdotal evidence .... that accomplished teachers recognise that the deepest levels of learning occur at the level of values, at the point where a student takes his or her learning and makes personal meaning from it. Without that connection at the values level, students can master the technical aspects of the curriculum but will be unlikely to value the learning experience or the school that provided it. (p. 82)

\section{Effective Values Education and Best Practice Pedagogy}

In speaking of the tempering role of values education, one is reminded of the caution against instrumentalist approaches to education that was provided by Dewey (1964) in the early days of public education. He said that to depend overly on subject knowledge and methods would be fatal to its best interests. He spoke, rather, of the need for a way of knowing that was about the cultivation of a mindset on the part of teachers that was, at one and the same time, self-reflective and directed towards instilling reflectivity, inquiry and a capacity for moral judiciousness on the part of students.

Another more recent but equally influential thinker worthy of mention in the context of tempering inclinations towards overly instrumental approaches to learning is Habermas (1972; 1974; 1984; 1987; 1990). Habermas's theory of knowing has been a significant influence in attempts by educationists to deepen understandings of learning and, in turn, in stretching conceptions of the role of the teacher. Beyond the importance of technical knowing (the knowing and understanding of facts and figures), Habermas spoke of the more challenging and authentic learning of what he described as historical-hermeneutic or 'communicative knowledge' (the knowing and understanding that results from engagement and interrelationship with others) and, moreover, of 'critical knowing' or 'self-reflectivity' (the knowing and understanding that comes from critique of all one's sources of knowledge and ultimately from critique of one's own self or, in Habermas's terms, from knowing oneself, perhaps for the first time). For Habermas, this latter was the supreme knowledge that marked a point of one's having arrived as a human being. One might caricature him as saying 'There is no knowing without knowing the knower', and the knower is oneself. In a sense, the ultimate point of the learning game is to be found in knowing oneself, and the consequent owning of beliefs and values that inevitably follows. 
Building on this, Habermas speaks of 'communicative capacity', which is when the self-reflective knower comes to see his or her own life-world as just one that needs to function in a myriad of life-worlds, and of 'communicative action', where the selfreflective knower takes a step beyond mere tolerance of other beliefs and values to take a stand both for justice and for oneself because one's new found self, one's own integrity, is at stake. This is a concept about personal commitment, reliability and trustworthiness that spills over into practical action that makes a difference, or what Habermas describes as 'praxis'. This is the kind of transformation of thought and practice that quality teaching seems to be directed towards and that an effective values education program would appear to have capacity to enhance.

Habermas's thought therefore provides a conceptual frame for the coalescing of quality teaching and values education. An implication of his thought is around the removal of any artificial division between knowing and values, since all knowing has an ethical component and is related in some way to human action, whether technical, communicative or reflective. This means that there is a values component in all learning, because knowing cannot be values-neutral, and, therefore, any learning entails an encounter with values related to a knowledge domain. The self-reflective element in knowing is the means by which implicit values of any knowledge domain become explicit to the knower.

\section{Quality Teaching and Explicit Values Education}

The experience of West Kidlington Public School in Great Britain, under the educational leadership of Neil Hawkes, offers a profound insight into the impact of values education on the quality of teaching and learning, when teacher attitudes and practices, curriculum both explicit and embedded, the school environment, and parental and community support are focussed on the betterment of student learning and achievement, academically, affectively, morally and spiritually. Fundamental to the approach at West Kidlington is respect for the child, and the forming of a relationship with each child is seen as essential to the fostering of each student's progress. Positive relationships between students, staff, parents and the wider community are a priority. Children are regarded as reflective learners and emphasis is placed on creating the kind of environment that will advance a child's capabilities through support, encouragement and engagement. Developing a stable emotional life so that children will be able to cope with the demands of secondary school without stress is of primary importance and such attention is devoted to the emotional state of children because of its determining effect on their willingness to learn. Evidence from Farrer (2000) and Hawkes (2005, 2007) shows that the benefits of the approach take the form of children being more emotionally stable, applying themselves better to their learning and being at greater ease in their relationships, including with adults. Furthermore, these positive effects have been shown to flow over to greater selfdiscipline and improved academic performance, as measured by a series of Ofsted inspections (Ofsted, 2007).

In other words, the content and substance of values education has the potential to go to the very heart of the power of quality teaching by focussing teacher and system attention on those features of their professional practice that have most impact, namely the relationship of due care, mutual respect, fairness and positive modelling established with the student and, in turn, the network of systemic 'relational trust' (Bryk \& Schneider, 1996, 2002) that results. As Clement (2007) sums up: 
The notion of quality teaching not only reflects the way the teacher is able to orchestrate the many different aspects of teaching into a coherent whole in order to encourage, guide and facilitate student learning. It also emphasizes the importance of a supportive classroom climate and the significance of positive values in creating an environment where student learning can flourish. (p. 21)

\section{Values Education and Good Practice Schools}

The Australian Government's 'Values Education Good Practice Schools’ project (VEGPS) has provided the opportunity for the theses and related evidence outlined above to be tested in multiple settings and using an array of values education criteria. The VEGPS Stage 1 Final Report (DEST, 2006) offers ample evidence that a wellconstructed values education has potential for profound effect on the whole educational system, affecting such variables as student achievement, school ethos, teacher practice, classroom climate, student attitudes and behaviours, and parental and community connections.

Much of the language of the testimony provided by teachers and university associates in the report captures well the intersection between matters relating to enhanced academic attainment and the depth of thinking, affirmative classroom climate and positive relationships implied in the nexus between quality teaching and values education. The report (DEST, 2006) speaks richly of an array of learning features that were enhanced by the various values education projects. These features included: quality teaching and pedagogy; holism in the approach to student development; quality relationships at all levels; values being both modelled and enunciated in the curriculum; enhanced intellectual depth in both teacher and student understanding; greater levels of student engagement in the mainstream curriculum; student willingness to become more involved in complex thinking across the curriculum; increased pedagogical approaches that match those espoused by quality teaching; greater student responsibility over local, national and international issues; greater student resilience and social skills; improved relationships of care and trust; measurable decline in the incidence of inappropriate behaviour; greater student awareness of the need to be tolerant of others, to accept responsibility for their own actions and their ability to communicate; improved students' sense of belonging, connectedness, resilience and sense of self; reflective change in the participant teachers and schools; provision of the opportunity to explore from within and reflect on identity and purpose; changed approaches to curriculum and pedagogy; enhanced students' ability to articulate feelings and emotions; impelling the emotional development of the students; evident transference in all aspects of classroom teaching and in the students' ability to deal with conflict in the playground; calmer and more cohesive classroom atmosphere; creation of a comfort zone for discussing emotions; improved levels of happiness for staff and students; developed higher order thinking skills; impelled restorative pedagogical practices; changed the ways teachers related with students; improved engagement and commitment of pupils, teachers and parents; valuing the need to create interpersonal intimacy and trust in the classroom; the 'ripple' or 'trickle-down' effect that values education had across the school.

Beyond these general sentiments, substantial testimony included the following: 
... the documented behaviour of students has improved significantly, evidenced in vastly reduced incidents and discipline reports and suspensions. The school is ... a 'much better place to be'. Children are 'well behaved', demonstrate improved self-control, relate better to each other and, most significantly, share with teachers a common language of expectations of values. Other evidence of this change in the social environment of the school is the significant rise in parental satisfaction. (p. 41)

The way that most teachers model behaviour to the students has changed. The way many teachers speak to students has changed. It is now commonplace for teachers to speak to students in values terms, ... for example, if a child has hurt another child, we would bring to the child's attention the values of 'Respect', 'Care' and 'Compassion' as well as 'Responsibility' for our actions... As a staff we realise the importance of modelling good behaviour and the values are the basis for this. (p. 75)

Everyone in the classroom exchange, teachers and students alike, became more conscious of trying to be respectful, trying to do their best, and trying to give others a fair go. We also found that by creating an environment where these values were constantly shaping classroom activity, student learning was improving, teachers and students were happier, and school was calmer. (p. 120)

... has provided many benefits to the students as far as a coordinated curriculum and learning experiences that have offered a sense of belonging, connectedness, resilience and a sense of self. However, there has been none more significant than the reflective change that has occurred in the participant teachers and schools. (p.185)

Thus, the VEGPS Project Report illustrates the dynamics of the reciprocal interaction of values education and quality teaching. With this evidence now in hand, we have ample demonstration that a well-constructed, clear and intentional values education program being integrated into the fabric of the school has the potential to bring transformational changes in the ethos of the school and the learning environment of the classroom, extending to student and teacher behaviour, beneficial effects on student motivation to learn and more than a hint of improved academic achievement.

Admittedly, this is evidence based largely at this stage on teacher testimony and the testimony of other stakeholders. The task before VEGPS Stage 2, currently in train, and of other research commissioned by the Australian Government, will be to test these findings by more empirical means to match the kind of empirical data now accessible in the USA in the context of character education (cf. Benninga et al., 2003, 2006; Fredericks, 2003) and in the UK via the kind of evidence that Hawkes (2005; 2007) has generated. At the same time, the contribution that Australia is making through VEGPSP and its allied projects should not be underestimated. The results of this work so far represent a unique groundswell of grounded theory about the impact of values education. Teacher testimony is, after all, the evidence that teachers look to most and that ultimately creates the momentum needed for wholesale change in teacher practice. The task before educational researchers is therefore to find ways of matching their own preferred evidence-based approaches with the evidence that 
counts most in teachers' minds in order to form a body of knowledge that proves the stated effects in indisputable fashion.

\section{Conclusion}

This article has identified the implicit values dimension that appears to be evident in research findings around quality teaching. It has furthermore set out to demonstrate that maximizing the effects of quality teaching requires explicit attention to this values dimension and that this can be achieved through a well-crafted values education program.

Our understanding of the role of the teacher, quality teaching and the power of values education are coalescing. No longer can values education be considered peripheral nor in any way the exclusive province of the religious school. Evidence suggests that, for the teacher and school intent on making the maximum impact on their students' wellbeing, values education lies at the centre of their respective roles. The nature, shape and purpose of values education has the potential to re-focus the attention of teachers and their systems on the fundamental item of all effective teaching, namely the teacher her or himself. This will include naturally the quality of the teacher's knowledge, content and pedagogy. Values education reminds us, however, that it will also include as an essential artefact the teacher's capacity to form the kinds of relationships with students that convey their commitment and care and that become the basis of developing in them personal character, effective citizenry and, as part and parcel of that, enhanced learners in all its dimensions. Establishing synergy and balance between values education and quality teaching goes to the heart of what effective teaching and schooling is all about. 


\section{References}

Alton-Lee, A. (2003). Quality teaching for diverse students in schooling: Best evidence synthesis. Retrieved December 1, 2005, from http:// www. minedu.govt. nz/ web/ downloadable/ dl8646 v1/ qualityteaching-for-diverse-students-in-schoo.pdf

Avery, P. G. (1999). Authentic assessment and instruction. Social Education, 63(6), 368.

Benninga, J., Berkovitz, M., Kuehn, P. \& Smith, K. (2003). The relationship of character education implementation and academic achievement in elementary schools. J ournal of Character Education, 1(1), 19-32.

Benninga, J., Berkovitz, M., Kuehn, P. \& Smith, K. (2006). Character and academics: What good schools do. Phi Delta Kappan, 87 (6), 448-452.

Brady, L. (2005). Dimensions of teaching. Curriculum and Teaching, 20(1), 5-14.

Bryk, A. S., \& Schneider, B. (1996). Social trust: A moral resource for school improvement. Chicago: Consortium on Chicago School Research. ERIC Document Service ED 412630.

Bryk, A. S., \& Schneider, B. (2002). Trust in schools: A core resource for improvement. New York: Russell Sage Foundation.

Campbell, R. J., Kyriakides, L., Muijs, R. D., \& Robinson, W. (2004). Effective teaching and values: some implications for research and teacher appraisal. Oxford Review of Education, 30(4), 451-465.

Carnegie. (1994). Years of promise: A comprehensive learning strategy for America's children: Executive summary. Retrieved December 14, 2005, from http:/ / www. carnegie. org/ sub/ pubs/ execsum. html

Carr, D. (2005). Personal and interpersonal relationships in education and teaching: A virtue ethical perspective. British J ournal of Educational Studies, 53(3), 255-271.

Carr, D. (2006). Professional and personal values and virtues in teaching. Oxford Review of Education, 32(2).

Cawsey, C. (2002). Naming, measuring and modelling the values of public education. In S. Pascoe (Ed.), Values in education: College year book 2002 (pp. 71-84). Deakin West, A.C.T.: Australian College of Educators.

Central Advisory Council for Education. (1967). Children and their Primary Schools ('The Plowden Report'). London: HMSO. Retrieved from http:// www.dg. dial. pipex.com/ plowden. shtml.

Clement, N. (2007). Perspectives from research and practice in values education. In T. Lovat \& R. Toomey (Eds.) Values education and quality teaching: The double helix effect. (pp. 13-27) Sydney: David Barlow Publishing.

Coleman, J. S., Campbell, E., Hobson, E., McPartland, J., Mood, A., Weinfied, F., et al. (1966). Equality of educational opportunity. Washington: U.S. Dept. of Health, Education, and Welfare, Office of Education; [for sale by the Superintendent of Documents, U.S. Govt. Print. Off.

Darling-Hammond, L. (1996). What matters most: A competent teacher for every child. Phi Delta Kappan, 78(3), 193-200.

Darling-Hammond, L. (1998). Teachers and teaching: Testing policy hypotheses from a National Commission report. Educational Researcher, 27(1), 5-15.

Darling-Hammond, L. (2000). Teacher Quality and Student Achievement: A Review of State Policy Evidence. Education Policy Analysis Archives, 8(1).

Darling-Hammond, L., \& Youngs, P. (2002). Defining "Highly Qualified Teachers": What does "Scientifically-Based Research" actually tell us? Educational Researcher, 31(9), 13-25.

Deakin-Crick, R. , \& Wilson, K. (2005). Being a learner: A virtue for the 21st century. British J ournal of Educational Studies, 53(3), 359-374. 
DEST. (2006). Implementing the National Framework for Values Education in Australian Schools: Report of the Values Education Good Practice Schools Project - Stage 1: Final Report September 2006. Retrieved 15 May, 2007, from http:// www. valueseducation. edu. au/ values/ default. asp?id=16381.

Fallon, D. (2003). Case study of a paradigm shift: The value of focusing on instruction. Retrieved 14 December, 2005, from http:/ / www.ecs.org/ clearinghouse/ 49/00/4900. htm

Farrer, F. (2000). A quiet revolution: Encouraging positive values in our children. London: Random House.

Fredericks, L. (2003). Making the case for social and emotional learning and service learning. In ECS Issue Brief, April (pp. 1-16) Denver, CO: Education Commission of the States. http:/ / education. csufresno.edu/ bonnercenter/ Relevant_Research/ Researc h_Support/ Social.pdf

Haberman, M. (2002). Can teacher education close the achievement gap? Paper presented at the American Educational Research Association Symposium April 2, 2002, New Orleans [Electronic Version]. EducationNews. org. Retrieved March 8, 2006 from http:// www. nuatc. org/ articles/ articles rec by. html.

Habermas, J . (1972). Knowledge and human interests (J. Shapiro, Trans. ). London: Heinemann.

Habermas, J. (1974). Theory and practice (J . Viertal, Trans.). London: Heinmann.

Habermas, J. (1984). The Theory of Communicative Action (T. McCarthy, Trans. Vol. One: Reason and the Rationalisation of Society). Boston: Beacon Press.

Habermas, J. (1990). Moral consciousness and communicative action (C. Lenhardt $\&$ S. W. Nicholsen, Trans.). Cambridge, MA: Massachusettes Institute of Technology Press.

Habermas, J. (2001). The liberating power of symbols: Philosophical essays (P. Dews, Trans.). Cambridge, UK: Polity Press.

Halliday, J . (1998). Technicism, reflective practice and authenticity in teacher education. Teaching and Teacher Education, 14(6), 597-605.

Hansen, D. T. (1998). The moral is in the practice. Teaching and Teacher Education, 14(6), 643-655.

Hattie, J . (2004). It's official: Teachers make a difference. Educare News, 144(February), 24, 26, 28-31.

Hawkes, N. (2005). Does teaching values improve the quality of education in primary schools? Unpublished PhD thesis, The University of Oxford, UK.

Hawkes, N. (2007). Values and quality teaching at West Kidlington school, UK. In T. Lovat \& R. Toomey (Eds.) Values education and quality teaching: The double helix effect. (pp. 115-133) Sydney: David Barlow Publishing.

House of Representatives Standing Committee on Education and Training. (2002). Boys: Getting it right: Report on the inquiry into the education of boys. Canberra, A.C.T.: The Parliment of the Commonwealth of Australia.

Hunt, A. (2004). Values: Taught or caught? Experiences of Year 3 students in a Uniting Church school. International Education J ournal, 4(4), 129-143.

J encks, C., \& et al. (1972). Inequality: A reassessment of the effect of family and schooling in America. New York: Basic Books.

Khine, M. S., \& Fisher, D. (2004). Teacher interaction in psychosocial learning environments: Cultural differences and their implications in science instruction. Research in Science and Technological Education, 22(1), 99-111.

King, M. B., Schroeder, J ., \& Chawszczewski, D. (2001). Authentic assessment and student performance in Inclusive schools, Brief\#5: Research Institute on Secondary Education Reform (RISER) for Youth with Disabilities. 
Leming, J. S. (1993). In search of effective character education. Educational Leadership, 51(3), 63-71.

Leming, J. S. (1994). Character Education and the Creation of Community [Electronic Version]. The Responsive Community, 4, 49-57. Retrieved May 8, 2006 from http:/ / www. gwu. edu/ ccps/ rcq/ issues/ 4-4. pdf.

Lickona, T. (1993). The return of character education. Educational Leadership, 51(3), 6-10.

Louden, W., Rohl, M., Barrat-Pugh, C., Brown, C., Cairney, T., Elderfield, J ., et al. (2005). In teachers' hands: Effective literacy teaching practices in the early years of schooling. Retrieved 27 November 2006, from http:/ / inteachershands. education. ecu. edu.au/.

Lovat, T. J . (2005). Values Education and Teachers' Work: A quality teaching perspective. National Values Education Forum, Australian Government Department of Education Science and Training Retrieved 28 November, 2006, from http:/ / www. valueseducation. edu. au/ values/ default. asp?id=8753

Lovat, T. (2007). Values education and quality teaching: Two sides of the learning coin. In T. Lovat \& R. Toomey (Eds.) Values education and quality teaching: The double helix effect. (pp. 1-12) Sydney: David Barlow Publishing.

Lovat, T. J ., \& Smith, D. (2003). Curriculum: Action on Reflection (Fourth ed.). Melbourne: Thomson.

Newmann, F. M. \& \& Associates. (1996). Authentic achievement: Restructuring schools for intellectual quality (1st ed.). San Francisco: J ossey-Bass Publishers.

Newmann, F. M., Marks, H. M., \& Gamoran, A. (1996). Authentic pedagogy and student performance. American J ournal of Education, 104, 280-312.

Noddings, N. (1997). Character education and community. In A. Molnar (Ed.), The construction of children's character (pp. 1-16). Chicago \&Great Britain: NSSE : Distributed by the University of Chicago Press.

NZ. (2005, 13 April). Impact of teaching and schools on variance in outcomes. Retrieved February 10, 2006, from http:/ / www. minedu. govt. nz/ index.cfm?layout =document\&documentid=867 $9 \&$ data $=$

Ofsted (2007). Inspection report: West Kidlington Primary School, 21-22 March, 2007. Manchester, UK: Office for Standards in Education.

Parsons, T. \& Bales, R. (1955). Family, socialization and interaction process. Glencoe, III: Free Press.

Reynolds, D., Hargreaves, A., \& Blackstone, T. (1980). Fifteen thousand hours: Secondary schools and their effects on children (Review Symposium of Rutter et al. Fifteen thousand hours). British J ournal of Sociology of Education, 1(2), 207-219.

Rowe, K. J. (2004). In good hands? The importance of teacher quality. Educare News, 149, 4-14.

Scanlon, L. (2004). 'She just blends and just comes down to our level and communicates with us like we're people': Students' perceptions of quality teaching and teaching standards. Change: Transformations in Education, 7(1), 93-108.

Scheerens, J., Vermeulen, C. J. A. J ., \& Pelgrum, W. J . (1989). Generalizability of instructional and school effectiveness indicators across nations. International J ournal of Educational Research, 13(7), 789-799.

Sergiovanni, T. J. (1996). Leadership for the schoolhouse: How is it different? Why is it important? (1st ed.). San Francisco: J ossey-Bass Publishers.

Sergiovanni, T. J . (2006). The principalship: A reflective practice perspective (5th ed.). Boston: Pearson/ Allyn and Bacon. 
Wentzel, K. R. (1997). Student motivation in middle school: The role of perceived pedagogical caring. J ournal of Educational Psychology, 89(3), 411-419.

Willms, J. D. (2000). Monitoring school performance for standards-based reform. Evaluation and Research in Education, 14(3\&4), 237-253.

Professor Terence Lovat is Pro Vice-Chancellor at The University of Newcastle, Australia. He is the chief investigator of the Australian Council of Deans of Education Values Education Project attached to the Australian Government's Values Education Program. 